
World Ecology

\title{
Eco-Environmental benefit assessment of the western route in China's South-North Water Transfer Project
}

\author{
Rongjin Yang , Guohua Liu , Jingzhu Zhao \& Bojie Fu
}

To cite this article: Rongjin Yang , Guohua Liu , Jingzhu Zhao \& Bojie Fu (2005) Eco-

Environmental benefit assessment of the western route in China's South-North Water Transfer Project, International Journal of Sustainable Development \& World Ecology, 12:4, 461-470, DOI: $10.1080 / 13504500509469654$

To link to this article: http://dx.doi.org/10.1080/13504500509469654

Published online: 24 Nov 2009.

Submit your article to this journal $\llbracket$

Џll Article views: 168

View related articles $₫$

Citing articles: 1 View citing articles ¿ð 


\title{
Eco-Environmental benefit assessment of the western route in China's South-North Water Transfer Project
}

Rongjin Yang, Guohua Liu, Jingzhu Zhao, Bojie Fu

Key Laboratory of Systems Ecology, Research Center for Eco-Environmental Sciences, Chinese Academy of Sciences, P.O. BOX 2871, Beijing 100085, China

Key words: Benefit assessment, China, eco-environment, water transfer; South-North Water Transfer, Western Route Project

\begin{abstract}
SUMMARY
Assessing the benefits of China's South-North Water Transfer project (SNWT) requires successful integration of an analysis of economic and eco-environmental benefits (EEB). To attain such integration, it is necessary to assess the EEB in detail, after the economic benefits have also been thoroughly assessed. The shadow engineering and market value methods are the major EEB assessment methods used in this study. We have assessed the $\mathrm{EEB}$ of the forest and grassland ecosystems in the recipient regions of the Western Route Project (WRP) for 2020, 2030 and 2050. Finally, some proposals are also made for efficient and sustainable management of the WRP.
\end{abstract}

\section{INTRODUCTION}

Water is one of the most important natural resources for the survival and development of humanity, integral to all environmental and social processes. Freshwater is scarce in China and the world in general (Björklund and Kuylenstierna 1998; Arnell 1999; Varis and Vakkilainen 2001). Socio-economic development and rapid population growth have made the situation worse, especially in northwest China (Feng and Cheng 1998). It is necessary to explore alternatives to alleviate this rapidly deteriorating and critical situation. One possibility is to transfer water over long distances from surplus to deficit areas. Already, many projects exist that divert water from one region to another (Golubev and Biswas 1979; Biswas et al. 1983; Snaddon et al. 1998; Feldman 2001). China's

South-North Water Transfer (SNWT) is among the largest water transfer projects in the world. There are three planned routes in SNWT - the eastern, middle and western routes (Yao and Chen 1983). The western route project (WRP) is the focus of this paper. The necessity and feasibility of the WRP in terms of engineering and economics has already been discussed ( $\mathrm{Li}$ et al. 2000; Jia 2001). However, other aspects should be considered, especially the social and environmental aspects (Biswas et al. 1983; Bruk 2001). The influence of the WRP on the eco-environment has also been considered (Song 1995; Qu 2001; Shang et al. 2001; Liu 2002; Wang 2002). The benefits to agricultural irrigation, domestic consumption and waterpower have been analyzed (Han et al. 1998). However, little attention

Correspondence: Guohua Liu, Key Laboratory of Systems Ecology, Research Center for Eco-Environmental Sciences, Chinese Academy of Sciences, PO Box 2871, Beijing 100085, China. Email: ghliu@rcees.ac.cn 
has been paid to the eco-environmental benefits. Our objective is to assess the eco-environmental benefits (EEB) of the recipient regions in the WRP.

\section{General layout of the WRP}

To assess the EEB in recipient regions, it is necessary to review the basic status of the WRP and its recipient regions. The WRP will perform two important functions: (1) to supply water directly to users (agricultural, industrial, domestic), and (2) to add water to the mainstream of the Yellow River The WRP will be completed in three stages:

1. The Da-Jia Line. This will lead from branches of the Da-Qu and Ni-Qu Rivers on the Ya-Long River to a branch of the Jia-Qu River, part of the Yellow River, via branches of the Du-Ke, Ma-Er-Qu and A-Ke Rivers on the Da-Du River. The amount of transferred water will be about four thousand million $\mathrm{m}^{3}$ by the year 2020 .

2. The A-Jia Line. This will lead from A-Da on the Ya-Long River to a Yellow River tributary, the Jia-Qu River. The amount of transferred water will be about five thousand million $\mathrm{m}^{3}$. So, by 2030, the total amount of transferred water will be about nine thousand million $\mathrm{m}^{3}$.
3. The Ce-Jia Line. This will lead from Ce-Fang on the Tong-Tian River to a Yellow River tributary, the Jia-Qu River. The amount of transferred water will be about eight thousand million $\mathrm{m}^{3}$.

Consequently, by 2050, the total amount of transferred water will be about seventeen thousand million $\mathrm{m}^{3}$ (Figure 1, Table 1) (Hu et al. 2001; Zhang et al. 2001). The main goal of the WRP is to resolve the problem of water deficiency in northwest China and to meet basic water use demands (especially the eco-environmental water demand) within the next 50 years in six provinces (Qinghai, Gansu, Ningxia, Shannxi, Shanxi and Inner Mongolia) of the upper and middle reaches of the Yellow River and its

Table 1 The water amount for different stages of the WRP (unit: hundred million $\mathrm{m}^{3}$ )

\begin{tabular}{lccc}
\hline & $\begin{array}{c}\text { For } \\
\text { industry } \\
\text { and living }\end{array}$ & $\begin{array}{c}\text { For eco- } \\
\text { Environment }\end{array}$ & $\begin{array}{c}\text { agricultural } \\
\text { irrigation }\end{array}$ \\
\hline $\begin{array}{l}\text { First stage (in 2020) } \\
\begin{array}{l}\text { Second stage } \\
\text { (in 2030) }\end{array}\end{array}$ & 23 & 17 & - \\
$\begin{array}{l}\text { Third stage } \\
\text { (in 2050) }\end{array}$ & 45 & 38 & 7 \\
\hline
\end{tabular}

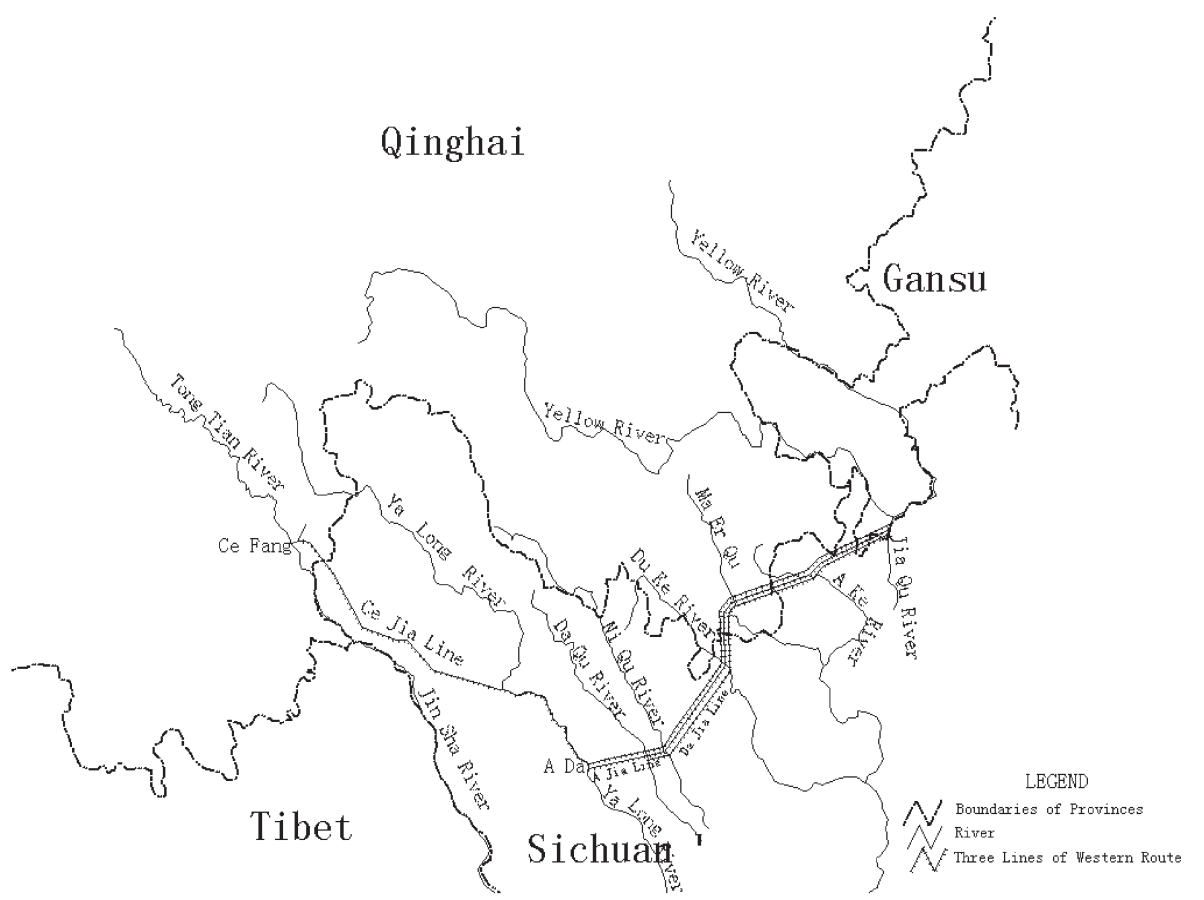

Figure 1 Sketch map of the Western Route project of the South-North Water Transfer project 
adjacent regions (Hexi corridor) (Zhang et al. 2001). Besides the agricultural ecosystem, forest and grassland are the main ecosystem types prevalent in the region. In this paper, the water amount for the eco-environment will be assigned to the forest and grassland ecosystems. The benefits to the forest and grassland ecosystems will be assessed individually. The benefits to industry, livelihoods and agricultural irrigation are not discussed here (Han et al. 1998).

\section{Recipient regions in the WRP}

The major recipient regions in the WRP (Figure 2) are located in the upper and middle reaches of the Yellow River, and constitute ecotones in China (Chang et al. 1999; Zhang et al. 2001). Their eco-environment has been seriously damaged. The situation is likely to become worse because of water deficit, rapid population growth and even more rapid economic development (Zhang and Xie 1999; He et al. 2000). The main eco-environmental problems are:

1. Desertification. China is one of the most severely desertified countries in the world. Approximately 400 million people and 3.3 million $\mathrm{km}^{2}$ of land have been affected (Chen et al. 1996; Zha and Gao 1997), and desertified areas expanded at an annual rate of $2103 \mathrm{~km}^{2}$ in the 1980s (Shou et al. 1992). The recipient regions for the water are among the most seriously desertified regions in China. Desertification has caused serious environmental problems, such as reduced soil fertility, damaged soil structure and reduced vegetation

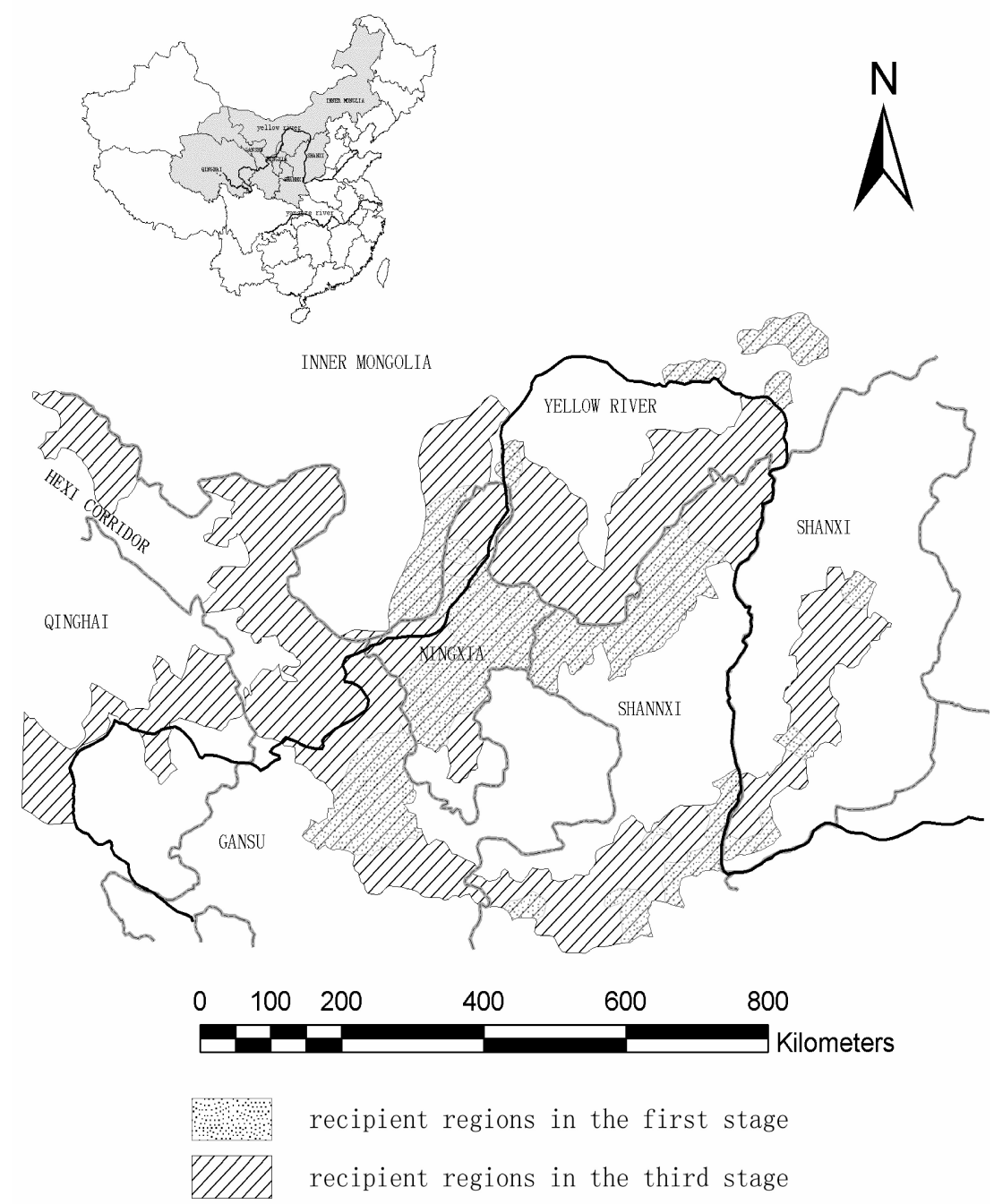

Figure 2 The recipient regions in the first and the third stages of the WRP 
quality and substantial economic losses (Zhu and Cui 1996).

2. Soil and water loss. The Chinese loess plateau is the most extreme soil and water loss area in the world. The area of loss is about $60 \%$ of the total land area, and the annual average soil loss is $2000-2500 \mathrm{t} \mathrm{km}^{-2}$ (Shi and Shao 2000). The majority of recipient regions for the water are located in the loess plateau. Soil and wate loss has seriously destroyed land resources and degraded the eco-environment.

3. Grassland degradation. In areas of northern China, such as Shanxi, degrading grassland represents about $95 \%$ of the total grassland area (Zhang 2001). The situation of grassland degradation is likely to become more serious, with problems of secondary salinization (Zhang and Li 2002), environmental pollution (Zhang and Li 2002) and decreased runoff (Tong et al. 2002).

4. Other eco-environmental problems experienced in Yellow River include drying up of the Yellow River (Song 1995; Cai and Yang 2002), waterway stagnation (Yin 2001), carbon loss (Lal 2003), decreasing vegetation cover (Piao and Fang 2001) and eco-environmental calamities (Wu et al. 2000).

These eco-environmental problems result from both natural (harsh natural conditions) and manmade causes (population overload, over-grazing and reclamation of waste land and deforestation). To resolve these problems, it is necessary to restore the vegetation. Water is the pivotal factor for vegetation restoration in northwest China (Zhang and L 2002). However, the degree of water deficit is serious (Zhang and Xie 1999; He et al. 2000; Qu 2001; Zhang et al. 2001), hence, the WRP provides means of resolving these problems.

\section{METHODOLOGY}

The EEB of different ecosystems were assessed according to their service functions and with two different methods, market value and shadow engineering methods (Huan 2001). The main service functions of forest and grassland ecosystems include the ability to: (1) conserve water, (2) preserve the soil, (3) fix sand, (4) mitigate wind, (5) fix $\mathrm{CO}_{2}$ and release $\mathrm{O}_{2},(6)$ purify the atmosphere, (7) decrease the loss of nutrient elements and organic materials $(\mathrm{OM})$, and (8) remediate other ecosystem service functions (Ou Yang et al. 1999). There are many methods of assessing ecosystem service functions.

\section{RESULTS}

To assess the EEB of the WRP, it is helpful to take the WRP as a whole, and to measure the average of the transferred water's allocation. The EEB will be assessed according to the different ecosystems, different service functions, different assessment methods and different parameters for 2020, 2030, and 2050 .

\section{Eco-environmental benefits resulting from water conservation}

Forest has an important water conservation function (Deng et al. 2002). To assess the EEB resulting from water conservation, the shadow engineering method was used. The major coefficients are the volume of increased water storage capacity, which is equal to the water conservation and engineering investment required per $\mathrm{m}^{3}$ of increased storage capacity. We assume that the water requirement of the forest (WRF) in northwest China is $11880 \mathrm{~m}^{3} \mathrm{ha}^{-1}$ year $^{-1}$. The water capacity (WC) of mature forest in northwest China is $1209.37 \mathrm{~m}^{3} \mathrm{ha}^{-1}$ year $^{-1}$ (Jiang 2002; Xu et al. 2003). The engineering investment (EI) required per $\mathrm{m}^{3}$ of storage capacity is 0.67 yuan $(\mathrm{RMB}) \times \mathrm{m}^{-3}(\mathrm{Ou}$ Yang et al. 1999)

$\mathrm{EEB} 1=\mathrm{TWF} \times \mathrm{WRF}^{-1} \times \mathrm{WC} \times \mathrm{EI}$

where EEB1 represents the EEB resulting from water conservation in the forest ecosystem. Table 2 can then be generated using equation (1). Grassland also has an important water conservation

Table 2 Eco-environmental benefits from water conservation

\begin{tabular}{lcccc}
\hline Year & $\begin{array}{c}\text { Transferred } \\
\text { water for forest } \\
\left(10^{8} \mathrm{~m}^{3}\right)\end{array}$ & $\begin{array}{c}\text { Irrigation } \\
\text { area of forest } \\
\left(10^{4} \mathrm{ha}\right)\end{array}$ & $\begin{array}{c}\text { Amount of } \\
\text { water held } \\
\left(10^{7} \mathrm{~m}^{3}\right)\end{array}$ & $\begin{array}{c}\text { Benefit } \\
\left(10^{8} \text { yuan }\right)\end{array}$ \\
\hline 2020 & 7 & 5.89 & 7.12 & 0.48 \\
2030 & 15 & 12.63 & 15.27 & 1.02 \\
2050 & 23 & 19.36 & 23.41 & 1.57 \\
\hline
\end{tabular}


function. However, the EEB from water conservation for grassland has not been assessed because of a lack of data. The assessment of EEB1 for 2020 2030 , and 2050 produces results of $0.48 \times 10^{8}$, $1.02 \times 10^{8}$ and $1.57 \times 10^{8}$ yuan (RMB), respectively.

\section{Eco-environmental benefits from fixing $\mathrm{CO}_{2}$ and releasing $\mathrm{O}_{2}$}

Forest and grassland fix $\mathrm{CO}_{2}$ and release $\mathrm{O}_{2}$. The methods of calculation used are the market value and shadow engineering methods (Guan et al. 2002). The major coefficients are the amount of fixed $\mathrm{CO}_{2}$ (AFC), the amount of released $\mathrm{O}$ $(\mathrm{ARO})$, the silvicultural cost (SC) for fixing $\mathrm{CO}_{2}$ and the cost of producing $\mathrm{O}_{2}(\mathrm{CPO})$. The productivity of the forest $(\mathrm{PF})$ is $1.132 \times 10^{4} \mathrm{~kg} \mathrm{ha}^{-1}$ year $^{-1}$ (Ou Yang et al. 1999). The transfer coefficient (TC) from biomass to carbon is 0.45 in the northwest of China (Hakkila 1989). The SC is $2.733 \times 10^{-1}$ yuan (RMB) $\mathrm{kg}^{-1}$. The cost of producing $\mathrm{O}_{2}(\mathrm{CPO})$ is equal to $4 \times 10^{-1}$ yuan (RMB) $\mathrm{kg}^{-1}$ (Ou Yang et al. 1999). Grassland water requirement (GWR) is $5625 \mathrm{~m}^{3}$ (Du 1991). The yield of hay (YH) is $1465 \mathrm{~kg} \mathrm{ha}^{-1}$ (Liao and Jia 1996). The ratio of stem/root of grass (RSR) is 0.24 (Fang et al. 1996).

$\mathrm{EEB} 2=\mathrm{TWF} \times \mathrm{WRF}^{-1} \times \mathrm{PF} \times \mathrm{TC} \times$

$$
(44 / 12) \times \mathrm{SC}
$$

EEB3 $=\mathrm{TWF} \times \mathrm{WRF}^{-1} \times \mathrm{PF} \times \mathrm{TC} \times$ $(32 / 12) \times \mathrm{CPO}$

$\mathrm{EEB} 4=\mathrm{TWG} \times \mathrm{GWR}^{-1} \times \mathrm{YH} \times\left(1+\mathrm{RSR}^{-1}\right) \times$

$$
\mathrm{TC}(44 / 12) \times \mathrm{SC}
$$

$\mathrm{EEB} 5=\mathrm{TWG} \times \mathrm{GWR}^{-1} \times \mathrm{YH} \times\left(1+\mathrm{RSR}^{-1}\right) \times$

$$
\mathrm{TC} \times(32 / 12) \times \mathrm{CPO}
$$

EEB2 and EEB3 represent the benefits for the forest from absorbing $\mathrm{CO}_{2}$ and releasing $\mathrm{O}_{2}$, respectively. EEB4 and EEB5 represent the benefits for the grassland from absorbing $\mathrm{CO}_{2}$ and releasing $\mathrm{O}_{2}$, respectively. The benefits resulting from fixing $\mathrm{CO}_{2}$ for the increased forest area can be assessed at $3.01 \times 10^{8}$ yuan $(\mathrm{RMB})$ in $2020,6.45 \times 10^{8}$ yuan $(\mathrm{RMB})$ in 2030 and $9.88 \times 10^{8}$ yuan $(\mathrm{RMB})$ in 2050 . The corresponding values for releasing $\mathrm{O}_{2}$ for the increased forest area amount to $3.20 \times 10^{8}$, $6.86 \times 10^{8}$ and $10.52 \times 10^{8}$ yuan (RMB) in 2020 , 2030 and 2050, respectively. For grassland, the corresponding benefits for fixing $\mathrm{CO}_{2}$ are $6.07 \times 10^{8}$, $13.96 \times 10^{8}$ and $18.20 \times 10^{8}$ yuan (RMB) in 2020 , 2030 and 2050, respectively; for releasing $\mathrm{O}_{2}$, $6.46 \times 10^{8}, 14.86 \times 10^{8}$ and $19.38 \times 10^{8}$ yuan $(\mathrm{RMB})$ in 2020, 2030 and 2050, respectively (Table 3 ).

\section{Eco-environmental benefits from retaining soil}

Forest and grassland can decrease the loss of soil, organic material $(\mathrm{OM})$ and nutrients in the soil, and they can decrease the stagnation of waterways, reservoirs and lakes. The methods of calculation used are the shadow engineering and market value methods (Hou et al. 1998). The amount of soil loss in wasteland (SLW) in northwest China is about $4.267 \times 10^{4} \mathrm{~kg} \mathrm{ha}^{-2}$ (Lu and Zhang 1995), and the ratio of forest soil loss to wasteland soil loss (RFW) is 5\% (Wu et al. 2002). We assume the ratio of grassland soil loss to wasteland soil loss (RGW) is equal to the RFW. Loess soil is the main soil type in northwest China and its soil bulk density (SBD) is $1.190 \times 10^{3} \mathrm{~kg} \times \mathrm{m}^{-3} \quad$ (Gansu Soil Survey Office 1993). The cost of building a reservoir (CBR) is 0.67 yuan $(\mathrm{RMB}) \times \mathrm{m}^{-3}$ (Ou Yang et al. 1999). The content of $\mathrm{OM}(\mathrm{COM})$ in the surface loess soil is $0.984 \%$. The content of $\mathrm{N}(\mathrm{CN})$ and of $\mathrm{P}(\mathrm{CP})$ are $0.068 \%$ and $0.064 \%$, respectively (Gansu Soil Survey Office 1993). The price of $\mathrm{OM}(\mathrm{POM})$ is $1.00 \times 10^{-2}$ yuan $(\mathrm{RMB}) \times \mathrm{kg}^{-1}$. The price of $\mathrm{N}$ $(\mathrm{PN})$ is 1.304 yuan $(\mathrm{RMB}) \times \mathrm{kg}^{-1}$. The price of $\mathrm{P}$

Table 3 Eco-environmental benefits from fixing $\mathrm{CO}_{2}$ and releasing $\mathrm{O}_{2}$

\begin{tabular}{llccccc}
\hline Year & Ecosystem & $\begin{array}{c}\text { Transferred water } \\
\left(10^{8} \mathrm{~m}^{3}\right)\end{array}$ & $\begin{array}{c}\text { Amount of } \mathrm{CO}_{2} \\
\text { fixed }\left(10^{9} \mathrm{~kg}\right)\end{array}$ & $\begin{array}{c}\text { Benefit of } \mathrm{CO}_{2} \\
\text { fixed }\left(10^{8} \text { yuan }\right)\end{array}$ & $\begin{array}{c}\text { Amount of } \mathrm{O}_{2} \\
\text { released }\left(10^{8} \mathrm{~kg}\right)\end{array}$ & $\begin{array}{c}\text { Benefit of } \mathrm{O}_{2} \text { released } \\
\left(10^{8} \text { yuan }\right)\end{array}$ \\
\hline \multirow{2}{2}{2020} & forest & 7 & 1.10 & 3.01 & 8.00 & 3.20 \\
& grassland & 10 & 2.22 & 6.07 & 16.15 & 6.46 \\
2030 & forest & 15 & 2.36 & 6.45 & 17.15 & 6.86 \\
& grassland & 23 & 5.11 & 13.96 & 37.14 & 14.86 \\
2050 & forest & 23 & 3.62 & 9.88 & 26.30 & 10.52 \\
& grassland & 30 & 6.66 & 18.20 & 48.44 & 19.38 \\
\hline
\end{tabular}


(PP) is $8.00 \times 10^{-1}$ yuan $(\mathrm{RMB}) \times \mathrm{kg}^{-1}$ (Hou et al. 1998).

$\mathrm{EEB} 6=\mathrm{TWF} \times \mathrm{WRF}^{-1} \times \mathrm{SLW} \times(1-\mathrm{RFW}) \times$ $\mathrm{CN} \times \mathrm{PN}$

$\mathrm{EEB} 7=\mathrm{TWF} \times \mathrm{WRF}^{-1} \times \mathrm{SLW} \times(1-\mathrm{RFW}) \times$ $\mathrm{CP} \times \mathrm{PP}$

EEB8 $=\mathrm{TWG} \times \mathrm{GWR}^{-1} \times \mathrm{SLW} \times(1-\mathrm{RGW}) \times$ $\mathrm{CN} \times \mathrm{PN}$

EEB9 $=\mathrm{TWG} \times \mathrm{GWR}^{-1} \times \mathrm{SLW} \times(1-\mathrm{RGW}) \times$ $\mathrm{CP} \times \mathrm{PP}$

EEB6 and EEB7 represent the benefits resulting from decreasing the $\mathrm{N}$ and $\mathrm{P}$ loss, respectively, for the increased forest area as a result of water transfer. EEB8 and EEB9 represent the benefits resulting from decreasing the $\mathrm{N}$ and $\mathrm{P}$ loss, respectively, for the increased grassland as a result of water transfer. The benefits resulting from decreasing the $\mathrm{N}$ loss as a result of the increased forest area are $2.12 \times 10^{8}$ yuan $(\mathrm{RMB})$ in $2020,4.54 \times 10^{8}$ yuan $(\mathrm{RMB})$ in 2030 and $6.96 \times 10^{8}$ yuan $(\mathrm{RMB})$ in 2050 The benefits from decreasing the $\mathrm{P}$ loss as a result of the increased forest are $1.22 \times 10^{8}$ yuan $(\mathrm{RMB})$ in $2020,2.62 \times 10^{8}$ yuan (RMB) in 2030 and $4.02 \times 10^{8}$ yuan $(\mathrm{RMB})$ in 2050 . For grassland, the corresponding benefits are $6.39 \times 10^{8}$ yuan $(\mathrm{RMB})$ in $2020,14.70 \times 10^{8}$ yuan $(\mathrm{RMB})$ in 2030 and $19.17 \times 10^{8}$ yuan $(\mathrm{RMB})$ in 2050 for decreasing
$\mathrm{N}$ loss; $3.69 \times 10^{8}$ yuan (RMB) in 2020 $8.49 \times 10^{8}$ yuan (RMB) in 2030 and $11.07 \times 10^{8}$ yuan $(\mathrm{RMB})$ in 2050 for decreasing $\mathrm{P}$ loss (Table 4$)$

The percentage of stagnation/soil loss is about 24\% (Ou Yang et al. 1999). The EEB resulting from decreasing the stagnation can be calculated as follows:

$\mathrm{EEB} 10=\mathrm{TWF} \times \mathrm{WRF}^{-1} \times \mathrm{SLW} \times(1-\mathrm{RFW}) \times$ $\mathrm{SBD}^{-1} \times \mathrm{CBR} \times 24 \%$

$\mathrm{EEB} 11=\mathrm{TWG} \times \mathrm{GWR}^{-1} \times \mathrm{SLW} \times(1-\mathrm{RGW}) \times$ $\mathrm{SBD}^{-1} \times \mathrm{CBR} \times 24 \%$

EEB10 and EEB11 represent the benefits resulting from decreasing stagnation for the increased forest and grassland areas, respectively, as a result of water transfer. The benefits from decreasing stagnation for the increased forest area are $0.32 \times 10^{8}$ yuan $(\mathrm{RMB})$ in $2020,0.69 \times 10^{8}$ yuan $(\mathrm{RMB})$ in 2030 and $1.06 \times 10^{8}$ yuan $(\mathrm{RMB})$ in 2050 . For grassland, the corresponding benefits are $0.98 \times 10^{8}$ yuan $(\mathrm{RMB})$ in $2020,2.24 \times 10^{8}$ yuan $(\mathrm{RMB})$ in 2030 and $2.92 \times 10^{8}$ yuan (RMB) in 2050 for decreasing stagnation (Table 5).

EEB resulting from decreasing the loss of OM are calculated as follow:

$\mathrm{EEB} 12=\mathrm{TWF} \times \mathrm{WRF}^{-1} \times \mathrm{SLW} \times(1-\mathrm{RGW}) \times$ $\mathrm{COM} \times \mathrm{POM}$

Table 4 Eco-environmental benefits from reducing loss of nutrient elements

\begin{tabular}{llcccccc}
\hline Year & Ecosystem & $\begin{array}{c}\text { Transferred water } \\
\text { forforest }\left(10^{8} \mathrm{~m}^{3}\right)\end{array}$ & $\begin{array}{c}\text { Amount of soil } \\
\text { held }\left(10^{11} \mathrm{~kg}\right)\end{array}$ & $\begin{array}{r}\text { Amount of } N \\
\text { held }\left(10^{8} \mathrm{~kg}\right)\end{array}$ & $\begin{array}{r}\text { Benefit of } N \\
\text { held }\left(10^{8} \text { yuan }\right)\end{array}$ & $\begin{array}{r}\text { Amount of } P \\
\text { held }\left(10^{8} \mathrm{~kg}\right)\end{array}$ & $\begin{array}{r}\text { Benefit of } P \\
\text { held }\left(10^{8} \text { yuan }\right)\end{array}$ \\
\hline 2020 & 7 & 2.39 & 1.62 & 2.12 & 1.53 & 1.22 \\
& forest & 10 & 7.21 & 4.9 & 6.39 & 4.61 & 3.69 \\
& grassland & 15 & 5.12 & 3.48 & 4.54 & 3.28 & 2.62 \\
& forest & 23 & 16.57 & 11.27 & 14.7 & 10.61 & 8.49 \\
& grassland & 23 & 7.85 & 5.34 & 6.96 & 5.02 & 4.02 \\
& forest & 23 & 14.7 & 19.17 & 13.84 & 11.07 \\
& grassland & 30 & 21.62 & 1.7 & &
\end{tabular}

Table 5 Eco-environmental benefits from decreasing water stagnation

\begin{tabular}{llcccc}
\hline Year & Ecosystem & $\begin{array}{c}\text { Transferred water } \\
\left(10^{8} \mathrm{~m}^{3}\right)\end{array}$ & $\begin{array}{c}\text { Amount of soil held } \\
\left(10^{11} \mathrm{~kg}\right)\end{array}$ & $\begin{array}{c}\text { Volume of stagnation } \\
\text { decreased }\left(10^{8} \mathrm{~m}^{3}\right)\end{array}$ & $\begin{array}{c}\text { Benefit of stagnation } \\
\text { decrease }\left(10^{8} \text { yuan }\right)\end{array}$ \\
\hline 2020 & forest & 7 & 2.39 & 0.48 & 0.32 \\
& grassland & 10 & 7.21 & 1.46 & 0.98 \\
2030 & forest & 15 & 5.12 & 1.03 & 0.69 \\
& grassland & 23 & 16.57 & 3.34 & 2.24 \\
2050 & forest & 23 & 7.85 & 1.58 & 1.06 \\
& grassland & 30 & 21.62 & 4.35 & 2.92
\end{tabular}


$\mathrm{EEB} 13=\mathrm{TWG} \times \mathrm{GWR}^{-1} \times \mathrm{SLW} \times(1-\mathrm{RGW}) \times$ $\mathrm{COM} \times \mathrm{POM}$

EEB12 and EEB13 represent the benefits resulting from decreasing $\mathrm{OM}$ loss for the increased fores and grassland areas, respectively, as a result of water transfer. The benefits from decreasing OM loss for increased forest are $0.24 \times 10^{8}$ yuan (RMB) in 2020 $0.50 \times 10^{8}$ yuan $(\mathrm{RMB})$ in 2030 and $0.77 \times 10^{8}$ yuan (RMB) in 2050. For grassland, the corresponding benefits are $0.71 \times 10^{8}$ yuan $(\mathrm{RMB})$ in 2020 $1.63 \times 10^{8}$ yuan $(\mathrm{RMB})$ in 2030 and $2.13 \times 10^{8}$ yuan (RMB) in 2050 for decreasing OM loss (Table 6).

\section{Eco-environmental benefits from purifying the atmosphere}

The forest ecosystem has the ability to absorb $\mathrm{SO}_{2}$ and to remove dust from the atmosphere (Guan et al. 2002). The amount of $\mathrm{SO}_{2}$ absorbed (ASA) by deciduous broadleaved and coniferous mixed forest is $152 \mathrm{~kg} \mathrm{ha}^{-1}$ year $^{-1}$. The amount of dust removed (ADR) by deciduous broadleaved and coniferous mixed forest is $2.17 \times 10^{4} \mathrm{~kg} \mathrm{ha}^{-1}$ year $^{-1}$ (Ou Yang et al. 1999). The cost of decreasing $\mathrm{SO}_{2}$ (CDS) is 10 yuan (RMB) $\mathrm{kg}^{-1}$. The cost of decreasing dust (CDD) is 0.3315 yuan (RMB) $\mathrm{kg}^{-1}$ (Kang and Tian 2002).

$\mathrm{EEB} 14=\mathrm{TWF} \times \mathrm{WRF}^{-1} \times \mathrm{ASA} \times \mathrm{CDS}$

Table 6 Eco-environmental benefits from reducing $\mathrm{OM}$ (organic material) loss of OM

\begin{tabular}{llccc}
\hline Year & Ecosystem & $\begin{array}{c}\text { Transferred } \\
\text { water for forest } \\
\left(10^{8} \mathrm{~m}^{3}\right)\end{array}$ & $\begin{array}{c}\text { Amount of } \\
\text { OM held } \\
\left(10^{9} \mathrm{~kg}\right)\end{array}$ & $\begin{array}{c}\text { Benefit of } \\
\text { OM held } \\
\left(10^{8} \text { yuan }\right)\end{array}$ \\
\hline 2020 & forest & 7 & 2.35 & 0.24 \\
& grassland & 10 & 7.09 & 0.71 \\
2030 & forest & 15 & 5.04 & 0.50 \\
& grassland & 23 & 16.31 & 1.63 \\
2050 & forest & 23 & 7.72 & 0.77 \\
& grassland & 30 & 21.27 & 2.13 \\
\hline
\end{tabular}

$$
\mathrm{EEB} 15=\mathrm{TWF} \times \mathrm{WRF}^{-1} \times \mathrm{ADR} \times \mathrm{CDD}
$$

EEB14 and EEB15 represent the benefits resulting from absorbing $\mathrm{SO}_{2}$ and removing dust, respectively, for the increased forest area because of water transfer. The benefits from absorbing $\mathrm{SO}_{2}$ because of the increased forest area are $0.90 \times 10^{8}$ yuan $(\mathrm{RMB})$ in $2020,1.92 \times 10^{8}$ yuan $(\mathrm{RMB})$ in 2030 and $2.94 \times 10^{8}$ yuan $(\mathrm{RMB})$ in 2050 . The benefits from decreasing dust because of the increased forest area are $4.24 \times 10^{8}$ yuan $(\mathrm{RMB})$ in $2020,9.08 \times 10^{8}$ yuan $(\mathrm{RMB})$ in 2030 and $13.93 \times 10^{8}$ yuan $(\mathrm{RMB})$ in 2050 (Table 7). The benefits resulting from absorbing $\mathrm{SO}_{2}$ and removing dust in the increased grassland area have not been assessed because of a lack of data.

\section{Sum of eco-environmental benefits}

Many other service functions have not yet been assessed, such as education, tourism, etc. Table 8 can be generated using the results from the above equations. The EEB are $15.73 \times 10^{8}$ yuan $(\mathrm{RMB})$ in $2020,33.68 \times 10^{8}$ yuan (RMB) in 2030 and $51.65 \times 10^{8}$ yuan $(\mathrm{RMB})$ in 2050 for the increased forest area as a result of water transfer. The corresponding benefits are $24.30 \times 10^{8}$ yuan $(\mathrm{RMB})$ in $2020,55.88 \times 10^{8}$ yuan (RMB) in 2030 and $72.87 \times 10^{8}$ yuan $(\mathrm{RMB})$ in 2050 for the increased grassland area as a result of water transfer.

\section{DISCUSSION}

Water, a limited and fragile resource, is different from other resources such as soil and vegetation (Savenije 2002). Water can be transferred over great distances. Opportunities to alter the distribution of water are immense (Biswas et al. 1983) and the WRP is one such opportunity. The WRP will bring about gigantic economic benefits. The direct economic benefit is about $213-809 \times 10^{8}$ yuan (RMB) for the recipient regions (Han et al. 1998). According to this study, the EEB are

Table 7 Eco-environmental benefits from absorbing $\mathrm{SO}_{2}$ and removing dust

\begin{tabular}{cccccc}
\hline Year & $\begin{array}{c}\text { Transferred water } \\
\text { forforest }\left(10^{8} \mathrm{~m}^{3}\right)\end{array}$ & $\begin{array}{c}\text { Amount of } \mathrm{SO}_{2} \\
\text { absorbed }\left(10^{6} \mathrm{~kg}\right)\end{array}$ & $\begin{array}{c}\text { Benefit of } \mathrm{SO}_{2} \\
\text { absorbed }\left(10^{8} \text { yuan }\right)\end{array}$ & $\begin{array}{c}\text { Amount of dust } \\
\text { removed }\left(10^{9} \mathrm{~kg}\right)\end{array}$ & $\begin{array}{c}\text { Benefit of dust } \\
\text { removed (10 }\end{array}$ yuan) \\
\hline 2020 & 7 & 8.96 & 0.90 & 1.28 & 4.24 \\
2030 & 15 & 19.19 & 1.92 & 2.74 & 9.08 \\
2050 & 23 & 29.43 & 2.94 & 4.2 & 13.93 \\
\hline
\end{tabular}


Table 8 Sum of eco-environmental benefits over time (units: $10^{8}$ yuan)

\begin{tabular}{lccr}
\hline Year & 2020 & 2030 & 2050 \\
\hline Forest & 15.73 & 33.68 & 51.65 \\
Grassland & 24.30 & 55.88 & 72.87 \\
Total & 40.02 & 89.57 & 124.52 \\
\hline
\end{tabular}

$40.02 \times 10^{8}$ yuan $(\mathrm{RMB})$ in $2020,89.57 \times 10^{8}$ yuan $(\mathrm{RMB})$ in 2030 and $124.52 \times 10^{8}$ yuan $(\mathrm{RMB})$ in 2050. The eco-environmental benefit value is on the low side because of the lack of assessment of some system service functions and the lack of consideration of the long-term impact of the ecoenvironment. Natural resources are ample in northwest China and this preponderance in natural resources will convert into economic predominance after the WRP is carried out (Liu et al. 2001) The eco-environment functions will become more important following the forthcoming economic development and improvements in the living standards.

Using transferred water in the WRP continuously and effectively to resolve the water deficit in northwest China is propitious for many reasons: for socio-economic development and improvement in the standard of living, for construction of an ecolog ical environment in the ecotone in northwes China, and for resolving the drying up of the Yellow River and stagnation of the riverbed. However, there is more work to do, of which water saving is the most important aspect. After the WRP is completed, the Yellow River and the recipient regions of the WRP will still have insufficient water (Zhang and Xie 1999; He et al. 2000). To encourage wate saving, raising the price of water is a useful tool (Liu et al. 2003). However, water is not an ordinary economic resource (Savenije 2002) and institutional reform and more comprehensive other reforms are also necessary (Summerton 1998; Chaturvedi 2001;
Feldman 2001; Jin and Young 2001; Yang et al. 2003).

The benefit resulting from agricultural irrigation is about 1.5 yuan $(\mathrm{RMB}) \mathrm{m}^{-3}$, the benefit from industry and lifestyle is about 5.5 yuan $(\mathrm{RMB}) \mathrm{m}^{-3}$, and the benefit resulting from waterpower is about 0.9 yuan (RMB) $\mathrm{m}^{-3}$. The direct economic benefit in the recipient regions in the WRP is about 4.73-4.15 yuan (RMB) $\mathrm{m}^{-3}$ (Han et al. 1998). According to this study, the benefit of the WRP resulting from the eco-environment is about 1.0 yuan $\mathrm{m}^{-3}$. In fact, the ecological implications of water transfer have been and continue to be inadequately addressed (Snaddon et al. 1998) because of the externality and concealment of ecological benefits. Water management in integrated environmental management should, therefore, consider the EEB more, and the ecological water requirement should be met.

The WRP will help to alleviate water scarcity in northwest China and is necessary for improvements in the eco-environment and for economic development. Saving water and integrated water management are also very important. Detailed ecological studies of the effects of water transfer have, so far, fallen on deaf ears in administrative, engineering and political circles (Snaddon et al. 1998). More attention should be paid to the ecological aspects of the WRP and more studies should now be done.

\section{ACKNOWLEDGEMENTS}

The authors thank Leif Söderlund, an economist at the MTT Agrifood Research, Finland for assistance. This article is supported by the Knowledge Innovation Program (KIP) of the Chinese Academy of Sciences (KZCX 3-SW-423) and the SUSDEV-CHINA project in the EU INCO-DEV programme (ICA4-CT-2002-10004). It is partly funded by the Development Plan of the State Key Fundamental Research (2002CB111505)

\section{REFERENCES}

Arnell NW. Climate change and global water resources. Global Environmental Change 1999;9: S31-S49

Biswas AK, Zuo D, Nickum JE and Liu C. Long-distance water transfer: A Chinese case study and

international experiences. Dublin: Tycooly International Publishing Ltd.; 1983

Björklund G and Kuylenstierna J. The comprehensive freshwater assessment and how it relates to water policy world-wide. Water Policy 1998;1:267-82 
Bruk S. Interbasin water transfer. Water Policy 2001;3: S167-S169

Cai X and Yang Z. Genesis and countermeasures on the cutoff of the Yellow River. Journal of Chengdu University of Technology 2002;29(2):199-205

Chang X, Zhao A and Li S. Spatial-Temporal Scale and Hierarchy of Vulnerable Ecotone. Journal of Deser Research 1999;19(2):115-19

Chaturvedi MC. Sustainable development of India' waters - some policy issues. Water Policy 2001;3 297-320

Chen G, Dong Z and Yan P. Desertification: International research topics and research strategies of China. Exploration of Nature 1996;15:1-15

Deng K, Shi P and Xie G. Water conservation of forest ecosystem in the upper reaches of Yangtze river and its benefits. Resources Science 2002;24(6): 68-73

Du G. Research on water requirement of natural arid steppe and semi-arid steppe. Grass of China 1991;1:46-9, 42

Fang J, Liu G and Xu S. Carbon pools of Chinese terrestrial ecosystems. In Wang G and Wen P (eds), Concentration and release monitor of greenhouse gases and their relative processes. Beijing: Environmenta Science Press; 1996:109-28

Feldman DL. Tennessee's Inter-Basin Water Transfe Act: a changing water policy agenda. Water Policy 2001;3:1-12

Feng $Q$ and Cheng G. Current situation, problems and rational utilization of water resources in arid north-western China. Journal of Arid Environments 1998;40:373-82

Gansu Soil Survey Office. Soil in Gansu. Beijing: Agriculture Press; 1993

Golubew GN and Biswas AK. Interregional water transfers: problems and prospects. Oxford: Pergamon Press; 1979

Guan W, Wang Z, Chen J, Zhang Q and Wang X. Evaluation of forest ecosystem services in Gongga Mountain. Journal of Beijing Forestry University 2002;24(4):80-4

Hakkila P. Utilization of residual forest biomass. Berlin: Springer-Verlag; 1989

Han Z, Tang M and Hu J. Benefit analysis of West Route Project in South-North Water Transfer Yellow River 1998;20 (8):24-6

He H, Chen $\mathrm{H}$ and Zhang Y. Rational usage of the transferred water of West Route Project in South-North Water Transfer. Yellow River 2000, 22(2):14-16

Hou X, Xu Y and Bi X. Study on conservative ecological benefits calculating of mountainous forest in Hebei Province. Bulletin of Soil and Water Conservation 1998;18(1):17-21
Hu J, Tang M, Niu J and Zhang G. Scheme of West Route Project in South-North Water Transfer. Yellow River 2001;23(10):13-14

Huan M. Summarizing the ecosystem service functions and their values. Ecological Economy 2001;12:41-3

Jia S. The economic feasibility proof of the South-to-North Water Transfer Project must be thoroughly carried out. Science and Technology Review 2001;7:17-20

Jiang W. Analysis and evaluation on water-holding function of main forest types in Anji region. Journal of Nanjing Forestry University (Natural Sciences Edition) 2002;26(4):71-4

Jin $\mathrm{L}$ and Young W. Water use in agriculture in China: importance, challenges, and implications for policy. Water Policy 2001;3:215-28

Kang W and Tian D. Economic evaluation of the public benefits of the forests in human: II Benefits of air-cleaning. Journal of Central South Forestry University 2002;22(1):7-10

Lal R. Soil erosion and the global carbon budget. Environment International 2003;29:437-50

Li Q, Cao T and Hu J. The indispensability and feasibility analysis of the South-North Water Transfer Scheme. Water resources and water engineering 2000;11(2):29-32, 39

Liao G and Jia Y. Rangeland resources of China. Beijing: Chinese Science and Technology Press; 1996

Liu C. South-North Water Transfer impact on the ecological environment. Haihe water conservancy 2002;1:1-5

Liu G, Cui $\mathrm{Q}$ and Zhang S. West Route Project of South-North Water Transfer is the strategic project of Western Development. Yellow River 2001;23(8): $18-19$

Liu J, Savenije HHG and Xu J. Water as an economic good and water tariff design: Comparison between IBT-con and IRT-cap. Physics and Chemistry of the Earth 2003:28:209-17

$\mathrm{Lu} \mathrm{Z}$ and Zhang X. Study on soil water's dynamic and benefits of conserving the soil and water of artifical rassland in Loess Plateau Resource and Environment in Arid Region 1995;9(1):40-9

Ou Yang Z, Wang X and Miao H. Aprimary study on Chinese terrestrial ecosystem services and their ecological-economic values. Acta Ecological Sinica 1999;19(5):607-13

Piao $\mathrm{S}$ and Fang J. Dynamic vegetation cover change over the last 18 years in China. Ouaternary Sciences 2001;21(4):294-302

Qu Y. Relationships between the West Part of 'Southern Water to North' Project and Chinese West Development. Journal of Arid Land Resources and Environment 2001;15(1):1-10 
Savenije HHG. Why water is not an ordinary economic good, or why the girl is special. Physics and Chemistry of the Earth 2002;27:741-4

Shang Y, Ding Z and Tong H. Influence analysis of West Route Project in South-North Water Transfer on ecological environment. Yellow River 2001 23(10):21-2

Shi $\mathrm{H}$ and Shao M. Soil and water loss from the Loes Plateau in China. Journal of Arid Environments 2000;45:9-20

Shou W, Li N, Zhou J, Zhang X and Zhao Y. Discussion on the fundamental models of controlling desertified land in China. Journal of Desert Research 1992;12(3):22-7

Snaddon CD, Wishart MJ and Davies BR. Some implications of inter-basin water transfers for river ecosystem functioning and water resources management in southern Africa. Aquatic Ecosystem Health and Management 1998;1:159-82

Song J. The western route of South-to-North Wate Transfer Project and improvement of ecologic environment in the Northwest China. Science and Technology Review 1995;6:23-5,18

Summerton N. The British way in water. Water Policy 1998;1:45-65

Tong C, Hao D, Gao X, Jiang Q and Yong S. Forecast on changes of steppe degradation patterns in the Xilin River Basin, Inner Mongolia: an application of Markov process. Journal of Natural Resources 2002;17(4):488-93

Varis $\mathrm{O}$ and Vakkilainen P. China's 8 challenges to water resources management in the first quarter of the 21st Century. Geomorphology 2001;41:93-104

Wang M. Influence of trans-valley moving water on ecological environment and its countermeasures. Environment Conservation 2002;3:32-5

Wu G, Li J and Zhao J. Fundamental ecological and environmental problems and its countermeasures in Northwestern China. Chinese Academic Sciences 2000;10:12-17

Wu Q, Zhao H and Liu X. Matching techniques for sustaining and improving the soil and wate conserving function of loess plateau vegetation (i) conditions for conserving soil and water in forest. Rural Eco-Environment 2002;18(2):50-2

$\mathrm{Xu}$ J, Wang L and Wang J. Analysis of water requirement for vegetation restoration in Loess Plateau, China. Yellow River 2003;25 (1):13-15

Yang H, Zhang X and Zehnder AJB. Water scarcity, pricing mechanism and institutional reform in northern China irrigated agriculture. Agricultural Water Management 2003;61:143-61

Yao B and Chen Q. South-North Water Transfer Project Plans. In Biswas AK, Zuo D, Nickum JE, Liu C (eds), Long-distance water transfer-a Chinese case study and international experiences. Dublin: Tycooly International Publishing Ltd.; 1983:128-49

Yin G. Characteristics of sediment outflow and analysis of he runoff needed by sediment outflow in the lower Yellow River. Journal of Sediment Research 2001;3:50-6

Zha Yand Gao J. Characteristics of desertification and its rehabilitation in China. Journal of Arid Environments 1997;37:419-32

Zhang $\mathrm{H}$ and Xie B. Analysis of the degree of water deficit in the water-in regions of West Route Project in South-North Water Transfer and in the water supply region of Yellow River. Yellow River 1999;21 (2):29-31, 37

Zhang J. Study on grassland degradation and its control strategies in Shanxi Plateau. Journal of soil and water Conservation 2001;15(2):49-52

Zhang S and Li J. Problems and countermeasures of agricultural soil and water environment in Northwestern region of China. Journal of Soil and Water Conservation 2002;16(4):78-81

Zhang X, He H, Chen $\mathrm{H}$ and Xiao S. Objectives and areas of West Route Project in South-North Water Transfer. Yellow River 2001;23(10):15-16

$\mathrm{Zhu} \mathrm{Z}$ and Cui S. Distribution patterns of desertified land and assessment of its control measures in China. China Environmental Science 1996;16:328-34 